\title{
The Problems of Psycholinguistic Research Methodology and Quantum Approach
}

\section{Завдання психолінгвістичної методології досліджень і квантовий підхід}

\author{
Alexander Kholod \\ Doctor in Philology, \\ Professor
}

\author{
Олександр Холод \\ доктор філологічних наук, \\ професор
}

\author{
E-mail: akholod@ukr.net \\ orcid.org/0000-0002-6851-0176
}

Vasily Stefanik Carpathian

National University,

Department of Journalism

57, Shevchenko Str., Ivano-

Frankivsk, Ukraine, 76000
Прикарпатський національний

університет імені Василя

Стефаника, кафедра журналістики

$\triangle$ вул. Шевченка, 57, м. Івано-

Франківськ, Україна, 76000

Original manuscript received July 12, 2018

Revised manuscript accepted February 12, 2019

\begin{abstract}
In the article, the author analyzes the problem of lack of knowledge about what could be the research methods in psycholinguistics from the standpoint of quantum theories.

The purpose of the study is to establish the possibility of combining the theoretical potential of modern psycholinguistics and the proven tenets of quantum theories and the formulation of the tasks of the intended combination.

Both the dialectic and the metaphysical methods have become the research methodology. From among the general scientific the author chose methods of analysis and synthesis, classification. The research methodology included the following main procedures: identification of criteria by which it is possible to further classify existing methods related to the study of human nature, self-actualization of its internal resources to improve their own health, luck and safety; defining the tasks of the psycholinguistic research methodology within the framework of the quantum theories
\end{abstract}


The Problems of Psycholinguistic Research Methodology...

and areas of knowledge methodology; determination of the probabilistic correlation of psycholinguistic research methods and the potential of the methods of the quantum approach to the study of human nature and the construction of a table based on the mentioned correlation; identification of the tasks of the psycholinguistic research methodology, taking into account the potential of the methods associated with the study of quantum processes, paradoxes and effects; presentation of recommendations and tasks of psycholinguistics in the application of quantum-method methods.

In the conclusions of his study, the author found that the methods of psycholinguistics are based on a materialistic basis and cannot be adequate and relevant for quantum psychology, the methods of which are close to non-materialistic. That is why, according to the author, the methodology of quantum psychology should be adopted, declaring that the human brain is not a place of generation of his consciousness, but only an instrument of perception and interpretation of the products of consciousness.

Key words: methods, quantum approach, psycholinguistic methods, methods of quantum mechanics, superposition.

\section{Вступ}

Актуальність дослідження. Сьогодні в наукових колах фахівців, які досліджують питання психолінгвістики, актуалізується важлива проблема, суть якої полягає у відсутності сталих власних методів дослідження. Серед психолінгвістичних методів частотним $є$ експеримент та його види (наприклад, асоціативний, двофакторний, багатофакторний). Згадані для прикладу методи не $є$ суто психолінгвістичними (більше вони - психологічні). Ситуацію вже понад 60 років (від 1956 року, коли була започаткована психолінгвістика) не змінюють «свіжі» методологічні ідеї, хоча наука швидко просувається вперед. Вважаємо, що сучасним психолінгвістам варто звернути увагу на ті методи, які можуть бути сформульовані в межах квантової механіки, квантової фізики й квантової психології. Остання, до речі, лише починає свій методологічний шлях.

Отже, сьогодні відсутні власні галузеві методи в психолінгвістиці. Досить проблематичними $є$ шляхи дослідження в квантовій механіці й квантовій психології. Саме тому пошук i формулювання методів сучасної психолінгвістики в межах доступних для сприйняття й максимально доказових постулатів квантових теорій вважаємо актуальною дослідницькою процедурою. 
Постановка проблеми. Проблемою є відсутність знань про те, якими можуть бути методи досліджень у психолінгвістиці з позицій постулатів квантових теорій.

Аналіз попередніх досліджень $i$ публікащзій. Впродовж останніх 15-20 років сучасна українська психолінгвістична методологічна література досить пасивно поповнюється новими розробками й детальним їх описом. Частіше дослідники звертаються до російськомовних джерел і посилаються як на вже класичні психолінгвістичні праці (Белянин, 2003; Выготский, 1934; Горелов \& Седов, 2004; Дридзе, 1984; Жинкин, 1958, 1964; Залевская, 1999; Зимняя, 1976; Леонтьев, 1969, 2003; Сахарный, 1989; Сорокин, 1998; Тарасов, 1991; Уфимцева, 2011; Фрумкина, 2006; Шахнарович \& Юрьева, 1990); частково (Карасик, 1992), так і на навчально-методичну літературу, в якій подекуди обговорюються методологічні проблеми (Белянин, 2003; Горелов \& Седов, 2004; Денисенко \& Чеботарева, 2008; Красных, 2001; Леонтьев, 1969, 2003; Пищальникова, 2007; Румянцева, 2004; Сахарный, 1989; Уфимцева, 2011; Фрумкина, 2006).

Серед українських психолінгвістичних методологічних $i$ навчально-методичних працьь відмічаємо публікації (Горошко, 2008; Засєкіна \& Засєкін, 2006, 2008; Калмикова, 2009; Куранова, 2012; Мартинек, 1991; Петрик, Присяжнюк \& Компанцева, 2011; Калмикова, Харченко, Дем'яненко \& Порядченко, 2007; Холод, 2008a, 2008b, 2014) та ін. Аналіз праць згаданих дослідників дає підстави виокремити декілька таких груп методів, які застосовуються тією або іншою мірою під час вивчення процесів породження та сприйняття мовлення.

Відома класифікація методів, котра належить О.О. Леонтьєву (Леонтьев, 2003: 73-83) і нараховує такі методи психолінгвістики, як: 1) експеримент (лінгвістичний, формувальний); 2) спостереження; 3) самоспостереження (інтроспекція). На жаль, О.О. Леонтьєв не подав ширшу класифікацію, хоча й мав на те підгрунтя.

Де в чому іншу класифікацію запропонувала C.I. Куранова (Куранова, 2012: 33-62), яка включила до неї такі методи (методики) психолінгвістики:

1) прямий експеримент (методика семантичного шкалювання, семантичної взаємодії, завершення речень, асоціативні методики); 
The Problems of Psycholinguistic Research Methodology...

2) непрямі експериментальні методи (експеримент Дж. Міллера (Миллер, 1968), Ф. Сміт і Дж. Міллер (Smith \& Miller, 1969), С. Ервін-Тріпп і Д. Слобін (Ervin-Tripp \& Slobin, 1966);

3) методики непрямого дослідження семантики;

4) методика компонентного аналізу;

5) метод класифікації (Миллер, 1968);

6) лінгвістичний експеримент;

7) формувальний експеримент;

8) дискурс-аналіз.

У наведеній класифікації ми, на жаль, не знаходимо очевидних груп класифікації, за якими можна було б чітко і порядкувати наявні методи (методики) психолінгвістичних досліджень.

Дослідники В. Денисенко й Є. Чеботарьова (Денисенко \& Чеботарева, 2008) розширили класифікацію методів і запропонували такий перелік методів психолінгвістики:

1) методи оцінки рівня володіння мовними засобами;

2) асоціативні експерименти;

3) класичні методи психолінгвістичного аналізу;

4) методи суб'єктивного шкалювання;

5) логіко-психологічний аналіз тексту;

6) методика проведення контент- та інтент-аналізу;

7) сучасні методи дискурс-аналізу;

8) методи комп'ютерного дослідження текстів.

До питання щодо ідентифікації чіткої системи психолінгвістичних методів звертався В. Белянін (Белянин, 2003), який серед таких методів називав декілька:

- «моделі породження, сприйняття, онтогенезу мови»;

- «асоціативний експеримент (вільне володіння, спрямований, ланцюговий) як найбільш розроблена методика аналізу психосемантики»;

- «метод семантичного диференціала i як метод психолінгвістики, і як методика експериментальної психосемантики»;

- «методика доповнення полягає в деформації мовного повідомлення і подальшому його пред'явленні досліджуваним для відновлення; використовується як діагностика мовного і немовного поведінки досліджуваних»;

- «методика закінчення речення служить для розуміння механізмів синтаксичної організації мовлення»; 
Завдання психолінгвістичної методології досліджень...

- «методи непрямого дослідження психосемантики для встановлення семантичних відстаней між об’єктами у висловлюваннях»;

- «градуальне шкалювання, при якому піддослідним пропонується розташувати ряд слів однієї семантичної групи «по порядку», використовується для виявлення альтернативних семантичних просторів, які не даються в словниках»;

- «методика визначення граматичної правильності (за прикладом Л.В. Щерби (Щерба, 1974) про Глокую куздру...), яка дозволяє отримати статистично достовірний матеріал із позиції носіїв мови»;

- «різні опитувальники, частіше пілотажні, що спрямовані на відбір матеріалу для подальших експериментів»;

- «методика прямого тлумачення слова, що служить для виявлення в повсякденній свідомості рядового носія мови складної картини співвідношення лексичного значення i внутрішньої форми слова»;

- «методики різних класифікацій (розбити матеріал на групи), дозволяють виявити когнітивні процеси досліджуваних» (Белянин, 2003).

В. Белянін зауважує, що до 2003 року дослідження психолінгвістів були «орієнтовані не на стереотипні, а на продуктивні й творчі можливості мови», ««формули», для яких ще тільки належить створити» (Белянин, 2003).

Серед відомих дослідників, які дотримувалися методологічних положень квантової теорії, варто назвати таких зарубіжних колег: С. Хамерофф і Р. Пенроуз (Hameroff \& Penrose, 2014a, 2014b); Дж. Гринштейн, А. Зайонц (Гринштейн \& Зайонц, 2012); А. Креспо, А. Родрігес-Гранільо, В.Т. Лім (Crespo, Rodriguez-Granillo \& Lim, 2017); С. Волінські (Волинский, 1997; Wolinsky \& Wilson, 1993); Р. Уілсон (Уиллсон, 2018). Питання квантової психології розробляли російські дослідники В. Аршинов (Аршинов, 1984); А. Бєлінський (Белинский, 2003); М. Зарічний (Заречный, 2007); М. Іванов (Иванов, 2012); М. Менский (Менский, 2011); А. Печенкин (Печенкин, 1999, 2013); В. Терехович (Терехович, 2014); В. Янчилин (Янчилин, 2010).

Наукових праць українських прибічників квантових теорій не так багато. До їх числа належать публікації I. Вакарчука 
(Вакарчук, 2012); О. Гавелі (Гавеля, 2013); М. Карп’юк (Карп’юк, 2007); В. Крутова (Крутов, 2014); С. Терещука (Терещук, 2015) та інших дослідників.

Як вважає К. Ногалес (Ногалес, 2018), до основних ідей квантових теорій відносять такі:

1) людина створена $з$ космічної матерії і є нею;

2) природа людини унікальна й простягається через час і простір;

3) усі наші думки, вчинки, діяльність впливають на навколишнє середовище;

4) уся природа складається з атомного й субатомного рівня, де й діють закони квантової механіки.

Квантово-механічні явища мають три найбільш вагомі особливості.

1. Незалежно від відстані стан двох і більше об’єктів завжди взаємопов'язаний. Таке явище у квантовій механіці називають нелокальністю і цілісністю (або парадоксом ЕйнштейнаПодольського-Розена).

2. Умови спостереження за об’єктом і сам спостерігач впливають на квантові явища, що доводиться різницею між тими станами, які фіксуються під час вимірювання об'єкта, і тими, коли об'єкт знаходиться поза увагою спостерігача. Іншими словами, фіксується редукція хвилевої функції, під час якої різноманіття станів (до вимірювання частка перебуває в будь-яких можливих станах одночасно) переходить до одного стану.

3. Виникнення, розпад і знищення часток, а також народження віртуальних часток виникають у результаті динаміки квантових явищ (Ногалес, 2018).

Перелічені три особливості квантово-механічних явищ наштовхують нас на усвідомлення того, що такі самі, важливі, особливості можуть бути й стосовно розуміння свідомості й мозку. Для психології є значимою найбільш актуальна проблема квантової механіки - взаємовідносини й розмежування суб'єкта й об'єкта пізнання, а також - свідомості й матерії. Щоправда в поглядах на згадану проблему дослідники розділилися на два табори. Представники першого табору вважають, що квантово-механічна реальність з'являється саме тоді, коли вона має взаємодію зі спостерігачем. Прихильники другого табору не погоджуються i 
стверджують, що квантово-механічної реальності взагалі не існує, оскільки $є$ лише ті показники квантових систем, які вдається зареєструвати завдяки практичному досвіду.

Разом із тим, апологети двох згаданих таборів близькі в думці про те, що вивчати квантово-механічну реальність неможливо без урахування результатів досліджень фахівців різних наук, як-то: біологія, фізіологія, хімія, фізика, медицина, філософія тощо. Вчені впевнені в тому, що будь-яка наука має справу, перш за все, 3 актами суб'єктивного сприйняття, що підкріплюються відчуттями. До того ж, процеси сприйняття відбуваються на базі спостереження й суб'єктивної інтерпретації світу. Звідси, обговорюючи будь-які процеси квантово-механічного порядку, ми зіштовхуємося 3 необхідністю звертатися до психології, iї категорій i понятійнотермінологічного апарату.

Саме тому, враховуючи квантово-механічні теорії та їхні інтерпретації, варто сьогодні говорити про цікаві результати вивчення функцій центральної нервової системи й процесів, що відбуваються в нейронних структурах мозку. Наприклад, ідея нейро-квантового комп'ютінгу, запропонована дослідниками С. Хамероффом і Р. Пенроузом (Hameroff \& Penrose, 2014a), які вважають мозок людини квантовим комп'ютером, оскільки мозок породжує цілісні образи за принципом властивостей квантових часток (пригадаймо парадокс Ейнштейна-Подольського-Розена, про який ми повідомляли вище). Цікавим також слід вважати передбачення щодо того, що досягнення нейронами мозку певного конкретного рівня суперпозиції тягне за собою появу свідомості. Звідси випливає, що якість думок людини прямо пропорційна певним моделям, схемам, які створюються станами нейронів та ïx мереж. Варто нагадати, що квантовий принцип формування думок стосується не лише окремих мисленнєвих актів, а й функціонування тих механізмів психіки, які здійснюються свідомістю взагалі. Квантовий принцип дозволяє описувати вибір свідомістю будь-якого одного варіанту з великої кількості варіантів тих образів дійсності, які зберігаються впродовж життя у свідомому й несвідомому досвіді людини. Як повідомляє К. Ногалес, теорія нейрокомп'ютингу велике значення приділяє так званим особливим мікротубулам, які $є$ білковими створеннями й «складають цитоскелет мозкових нейронів». Вони $є$ системами, що здатні до самоналагодження й 
The Problems of Psycholinguistic Research Methodology...

«беруть участь у виникненні та організації квантових коливань мозку» (Ногалес, 2018). Згадані мікротубули регулюють функції синаптичних зв'язків і роблять вільними нейромедіатори. Також вони передають i «опрацьовують» інформацію між клітинами, при цьому взаємодіють 3 іншими клітинами й створюють цілісні клітинні структури. На думку К. Ногалеса, мікротубули порожні всередині, а значить мислення людини зароджується з порожнини.

Квантовий підхід пояснює вірогідність мислення, дослідження якого систематично й впродовж багатьох років здійснював нобелівський лауреат американський нейропсихолог Р. Сперрі (Sperry, 1964, 1969).

Дослідник встановив, що оскільки права півкуля «відповідає за несвідоме, чуттєве, нелінійне мислення», вона «не відчуває видимих причинно-наслідкових зв'язків, із чого випливає стан невизначеності майбутнього, тому що реалізуватися можуть абсолютно різні непередбачувані випадковості» (Ногалес, 2018). Свідомість має можливість одразу «бачити» усі можливі варіанти розвитку подій. Саме тому вона «звертається» до інтуїції, що підтверджується парадоксами квантової механіки. На базі відкриття Р. Сперрі з'явився метод інтуїтивного малювання, який розробила Бетті Едварде (Эдварде, 2000).

Як відомо (20 интересных фактов о мозге, 2018), мозок має приблизно 100 мільярдів нейронів (клітин, що генерують i передають нервові імпульси), що робить його подібним до комп'ютера як до приладу, який має потужний потенціал, але, разом із тим, не варто, як вважає К. Ногалес, вважати свідомість атрибутом мозку (Ногалес, 2018). I додає: оскільки людина є носієм свідомості, для пізнання цієї свідомості потрібно перейти на більш вищий рівень усвідомлення.

Поява цікавих і нетривіальних положень квантової механіки «запустила» механізм появи нового погляду і в психології. Один iз напрямків, про який вперше почали говорити в 90-х роках $\mathrm{XX}$ століття i який сьогодні стрімко розвивається, називають «квантова психологія». Остання, на думку К. Ногалеса (Ногалес, 2018) спирається на такі чотири основних принципи:

1) «людина є квантом інтелектуальної системи Всесвіту, і їхні процеси й алгоритми еволюційного розвитку взаємопов'язані; 
2) Всесвіт і його інтелектуальні системи меншого порядку підпорядковані стратегічному управлінню і безперервному процесу підтримки на кожному етапі життєвого циклу;

3) людина - це впорядкована наносистема, у якій протікають свої нанопроцеси, що складаються 3 речовини й енергоінформаційних компонентів;

4) інформаційне суспільство як еволюційний етап розвитку людства на Землі засноване на сингулярності свідомості людини, що базується на єдності та взаємозв'язку речовини й енергії у Всесвіті (включаючи процеси трансформації та перетворення)» (Ногалес, 2018).

Квантова психологія приймає як аксіому положення про те, що особистість як і матерія, що оточує іiі, $\epsilon$ неподільною сутністю Всесвіту як системи. Разом із тим, сама особистість не підозрює про те, що має прихований від погляду й усвідомлення прошарок реальності на рівні субатомної єдності. Оскільки є атомна єдність, яку кожна особистість може спостерігати (власне тіло: руки, ноги, шкіра тощо), і $є$ субатомна невидима єдність, яку спостерігати неможливо, з'являються підстави вважати, що людина існує одночасно в двох (якнайменше) вимірах, реальностях. Останнє наше твердження відповідає тезам квантової механіки, а отже, i квантової психології. Кожна реальність функціонує за своїми чіткими законами й принципами і найголовніше те, що між собою згадані реальності взаємопов'язані.

Варто також згадати про ще одну категорію квантової механіки - суперпозицію, яка для методології психолінгвістики є важливою. Наприклад, звертаючись до породження або сприйняття мовлення дослідник повинний врахувати дискурс. Під останнім розуміємо як саме мовленнєве утворення, так й оточення, у якому воно народжується. Конкретний дискурс формує конкретний стан особистості й конкретні прояви конкретних особистісних рис. Якщо змінити дискурс, можна отримати інший конкретний стан особистості й інші прояви особистісних рис. Це означатиме вплив спостерігача на результати вимірювання. Такий підхід відповідає категорії суперпозиція у квантовій механіці: до початку вимірювання дослідник як спостерігач не може точно знати про те, який стан особистості може бути в конкретний час. Варто пригадати, що в суперпозиції «атом розуміється як сума його індивідуальних 
The Problems of Psycholinguistic Research Methodology...

квантових станів... Коли ці різні стани або паралельні світи складаються, або накладаються один на одного, вони створюють загальний паттерн, або квантову хвилю» (Минделл, 2018). Стосовно квантової психології - розуміння різних станів розуму тлумачиться за допомогою уявлення про накладання різних рівнів свідомого й несвідомого як прошарків, що в сумі складають загальне поняття розуму. Іншими словами, розум є голографією й те, яку саме думку-імпульс вихопить для вербалізації, свідомість контролює не повною мірою.

Таким чином, обговорюючи декілька проблем квантової психології, що спираються на закони й принципи квантової механіки, можемо констатувати появу об'єктивної необхідності застосовувати їх під час формування нової методології для сучасних психолінгвістичних досліджень.

Meта дослідження полягає у встановленні можливості поєднання теоретичного потенціалу сучасної психолінгвістики й доведених постулатів квантових теорій i формулюванні завдань загаданого поєднання.

Виходячи із сформульованої мети дослідження, можемо виокремити об'єкт і предмет вивчення.

Об'єктом було обрано теоретичний потенціал сучасної психолінгвістики й доведених постулатів квантових теорій, предметом - визначення завдання в поєднанні згаданих потенціалу й постулатів.

\section{Методи та методики дослідження \\ (висвітлюсться проиедура теоретико-методологічного та/або експериментального дослідження)}

Для реалізації поставленої мети нам необхідно сформулювати методологію наукового пошуку, що ми здійснили, звернувшись до класифікації методів, запропонованої нами раніше (Холод, 2014). Із двох груп методів, які ми запропонували вирізняти, із першої групи (методи емпіричного дослідження) ми обрали спостереження як цілеспрямоване й організоване сприйняття методологічних систем у межах психолінгвістики та квантових наук. Із другої групи методів (методи теоретичного дослідження) для нашого дослідження було 
обрано аксіоматичний метод, що передбачав висування положень, які не вимагають доведення, і виведення на їх основі тез, що утворюють аксіоматичні підвалини для встановлення можливості поєднання теоретичного потенціалу сучасної психолінгвістики й доведених постулатів квантових теорій.

За іншою класифікацією методів наукового пізнання (загальні методи, загальнонаукові й спеціалізовані методи) для вивчення процесів формування психолінгвістичної методології потрібен діалектичний підхід (загальні методи), який передбачає пошук причинно-наслідкових зв'язків між психолінгвістичною методологією досліджень і квантовим підходом 3 урахуванням законів, принципів i категорій постійного їх розвитку. Але для пізнання квантового підходу недостатньо застосувати методи лише діалектики, оскільки поняття «квант» потребує більше не матеріалістичних методів пошуку істини, а вимагає враховувати потенціал метафізики як методу. Останній передбачає формулювання завдань психолінгвістичної методології досліджень i квантового підходу 3 урахуванням цілісності таких завдань, їхньої неподільності, без застосування базових питань логіки й існуючої теорії.

Із числа загальнонаукових ми обрали метод аналізу й метод синтезу, за допомогою яких спочатку розчленували поняття «психолінгвістична методологія» і «квантовий підхід» на смислові складники, а потім з'єднали лише ті виокремленні характеристики згаданих понять, які слугували досягненню мети нашого дослідження. Також ми звернулися до методу класифікації. При цьому розподілили існуючі психолінгвістичні методи на групи в залежності від їхніх ознак, зафіксували закономірні зв'язки між групами й перенесли їх в систему квантового підходу.

3 урахуванням основних параметрів нашого звіту (проблема, предмет вивчення, історія дослідження й мета наукового пошуку) надалі ми сформували методику дослідження, основними процедурами якої стали такі:

1) пошук наукових джерел, автори яких тією або іншою мірою застосовували методи психолінгвістики й квантової механіки, квантової психології та квантової психотерапії у своїх наукових розвідках; 
The Problems of Psycholinguistic Research Methodology...

2) аналіз ненаукових джерел, у яких автори згадують про наукові методи психолінгвістики й «квантових» галузей знань, згаданих у п. 1);

3) ідентифікація критеріїв, за якими можлива подальша класифікація існуючих методів, що пов'язані з вивченням природи

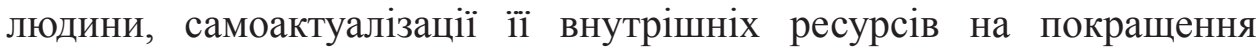
власного здоров'я, успіху й безпеки;

4) визначення завдань психолінгвістичної методології досліджень у межах методології квантових теорій і галузей знань;

5) визначення вірогіднісної кореляції психолінгвістичних методів досліджень i потенціалу методів квантового підходу до вивчення природи людини й побудова таблиці на базі згаданої кореляції;

6) визначення завдань психолінгвістичної методології досліджень 3 урахуванням потенціалу методів, що пов'язані 3 вивченням квантових процесів, парадоксів та ефектів;

7) побудова теоретичної моделі завдань, згаданих у п. 6.

\section{Результати та дискусії}

Аналіз класифікації методів, запропонованих О.О. Леонтьєвим не можна сьогодні вважати достеменним і досконалим, оскільки від часу появи такої класифікації (Леонтьев, 2003) минуло більше двадцяти років, упродовж яких де в чому змінилися підходи до аналізу психолінгвістичних процесів. Нові електронні технології дозволили змінити й методи вимірювання психолінгвістичних одиниць i явищ. Після трьох (експеримент, спостереження, самоспостереження), запропонованих О.О. Леонтьєвим методів найширшою за діапазоном слід вважати класифікацію методів психолінгвістики, яку запропонував В.П. Белянін (Белянин, 2003), хоча 311 методів (і методик, які можуть сьогодні вважатися методами) два методи (експеримент і методи аналізу з урахуванням моделей породження й сприйняття мовлення) вже були в різних інтерпретаціях записані в класифікації О.О. Леонтьєва (різні види експериментів).

До існуючих класифікацій дослідники В. Денисенко й Є. Чеботарьова (Денисенко \& Чеботарева, 2008) додали ще шість (методи оцінки рівня володіння мовними засобами; методи 
суб'єктивного шкалювання; логіко-психологічний аналіз текста; методика проведення контент- та інтент-аналізу; сучасні методи дискурс-аналізу; методи комп’ютерного дослідження текстів).

Слід зазначити, що перелічені методи, описані дослідниками психолінгвістики В. Денисенко й Є. Чеботарьовою, мають достатньо детальні характеристики. Але разом із тим, згадана деталізація не пояснює те, чому автори не розрізнюють значення термінів «метод» $\mathrm{i}$ «методики». Остання обставина робить розмитою подану класифікацію й змішує поняття методу як основного шляху дослідження й методики як дослідницької процедури. Тут варто занотувати, що така плутанина запозичена авторами зарубіжної психолінгвістики, де поняття «метод» і «методика» традиційно не диференціюються.

Не набагато розширила класифікацію методів психолінгвістики C.I. Куранова (Куранова, 2012), яка 2012 року додала ще чотири методи (методики непрямого дослідження семантики; методика компонентного аналізу; метод класифікації, запропонований Дж. Міллером; дискурс-аналіз), що розширило діапазон дослідницьких інструментів, але поза увагою залишило багато тих методів, які називали на той час або техніками.

Таким чином, неглибокий аналіз історії опрацювання й розробки проблеми ідентифікації психолінгвістичних методів у сучасному вітчизняному науковому дискурсі дає нам підстави констатувати кілька тез:

1) сьогодні не існує єдиної деталізованої класифікації психолінгвістичних методів дослідження;

2) ті класифікації, які були раніше запропоновані авторами, мають вірогідно розмиті критерії, що, в свою чергу, не могло забезпечити чітку диференціацію методів на типи й види;

3) відсутність чіткої класифікації психолінгвістичних методів об'єктивно вимагає своєчасної пропозиції або нової уточненої класифікації, або доповнення до вже існуючих класифікацій 3 урахуванням методологічного потенціалу наук, що з'являються на початку XXI століття.

Для ідентифікації й формулювання завдання психолінгвістичної методології досліджень із урахуванням квантового підходу зручними були спеціалізовані (або галузеві) методи й категорії. У психолінгвістиці такими були контент-аналіз, інтент-аналіз. 
The Problems of Psycholinguistic Research Methodology...

Відомо, що у квантовому підході методи застосовуються до конкретних фізичних, хімічних й механічних середовищ. Саме тому ми, враховуючи об’єкт дослідження (теоретичний потенціал сучасної психолінгвістики й доведених постулатів квантових теорій), звернулися до згадування в наукових джерелах лише тих методів, які зарекомендували себе як сталі й вже традиційні. До таких методів квантової механіки слід віднести:

- метод валентних схем (ВС) або метод локалізованих електронних пар;

- метод конформаційного аналізу;

- метод об'єднаного атому;

- операторний метод;

- наближені методи квантової механіки;

- варіаційний метод наближеного рішення рівняння Шредінгера;

- асимптотичні методи та інші.

Перелічені методи не є методами, що можуть розтлумачити психічні процеси, а тому ми звернулися до методів, які пропонують дослідники квантової психології. Серед таких методів ми знайшли:

- метод квантово-механічного впливу хвилями резонансних коливань (медичний термін - MPТ, або використання електромагнітних випромінювань украй високої частоти низької інтенсивності - ЕМВ УВЧ НІ) (Лазуренко, 2010: 607);

- метод картування світу (Wilson, 2018);

- квантовий метод як метод досвіду (Dominquez, 2018).

Сьогодні відомі спеціальні методи в психотерапії, яка спирається на принципи квантової механіки. До таких методів К. Ногалес (Ногалес, 2018). відносить:

- терапія мисленнєвого контролю;

- тетахілінг;

- метод прямого сприйняття;

- метод сутнісної трансформації;

- метод символічного моделювання.

Дослідник А. Нефедов (Нефедов, 2018), вивчаючи управління реальністю за допомогою квантової психології, пропонує застосовувати такі методи (іноді автор називає їх методиками):

- метод (методика) позитивного програмування;

- метод імплозивної терапії (запозичений у психоаналізу). 
Доктор Марко Парет (Paret, 2018), який багато років застосовує потенціал квантової психології, пропонує:

- метод (методику) присутності;

- метод (методику, техніку) тривоги та дискомфорту;

- масаж ipnogeno (поєднання масажу й гіпнозу);

- метод месмеризму (глибоке зцілення шляхом уведення в транс й екстатичний стан).

Прибічники квантового підходу в психології практикують метод thetahealing (тетахілінгу), або «спосіб швидко й гарантовано вводити мозок у стан Тета (Theta), зберігаючи при цьому усвідомленість і волю до дії» (Чему обучает методика ThetaHealing, 2018). Згаданий метод запропонувала Віанна Стейбл, яка сама себе вилікувала від раку.

Роберт Антон Вілсон, у своїй праці «Квантова психологія» називає декілька методів, на які повинна спиратися квантова психологія, а саме:

- метод прагматизму, прибічники якого стверджують, що «ідеї мають сенс тільки в конкретних людських ситуаціях, «істина» як абстракція не має сенсу взагалі» (Уиллсон, 2018);

- екзистениіалістські методи, що містять в собі феноменологічний метод Е. Гуссерля;

- операціоналістські методи (включаючи метод «зниклої» маси);

- метод Станіславського, коли кожний повинний «представити точку зору іншого, як можна щиро» (Уиллсон, 2018);

- метод «чистого абстрактного умовиводу» (застосовувався Платоном й Аристотелем, які вважали, що «цей метод призведе до Чистої Істині, яка вільна від будь-яких спотворень, пов'язаних із недосконалістю людських органів почуттів» (Уиллсон, 2018);

- метод сестри Кенні, суть якого полягала в «а) елементах зцілення вірою, б) масажі м'язів і в) тривалому вимочуванні пацієнта в гарячих ваннах» (Уиллсон, 2018).

Перелічені методи (методики, технології), на жаль, не $\epsilon$ сталими на сьогодні в галузях знань, що спираються на квантову механіку. Підтвердженням нашої думки є те, що автори «жонглюють» термінологією i називають методами методики дослідження. Іноді практичні техніки автори також називають 
The Problems of Psycholinguistic Research Methodology...

методами, що вносить серйозну плутанину в спроби молодих науковців опанувати запропоновані системи поглядів.

До критичних слід також віднести й зауваження, що стосується відсутності єдиних критеріїв, за якими постала б можливість чіткої класифікації тих методів, які спираються на досягнення квантової механіки.

Поданий нами раніше перелік методів, що іноді називаються авторами методиками й техніками, стосується різних наукових галузей і медичних практик, що не дає можливості об'єднати їх під однією назвою, наприклад, «наукові методи квантової теорії». Згадана причина не дозволяє ідентифікувати чіткі критерії для бажаної класифікації.

Названі причини об’єктивно створюють певний методологічний «вакуум» i як результат демонструють впродовж вже майже 100 років відсутність верифікованої методології як системи конкретних методів і квантового підходу й квантової психології зокрема.

Найбільш серйозною, на наш погляд, причиною столітнього методологічного вакууму у квантовому підході до вивчення природи людини $є$ майже повна гіпотетичність результатів спостережень i відсутність конкретних фактів, що підтверджували б висунуті теорії й концепції в межах квантового підходу.

Разом із тим, вважаємо найбільш сталими не стільки методи квантового підходу, скільки ті категорії, які слугують відправними пунктами функціонування самого квантового підходу. Мовиться про 5 таких понятійних категорій:

1) «квант як енергія»,

2) «єдність людини і Всесвіту»,

3) «суперпозиція»,

4) «Всесвіт керований»,

5) «людина $є$ енергоінформаційною системою».

Із метою здійснення спроби ідентифікації зв’язку між згаданими раніше методами психолінгвістики і методами квантового підходу, спираючись на перелічені 5 понятійних категорій останнього, ми склали табл. 1.

Аналіз та обговорення показників табл. 1 свідчить про такі особливості:

1) нами ідентифіковано 34 психолінгвістичні методи й 29 методів квантової психології, що разом склало 63 (100%) методи; 


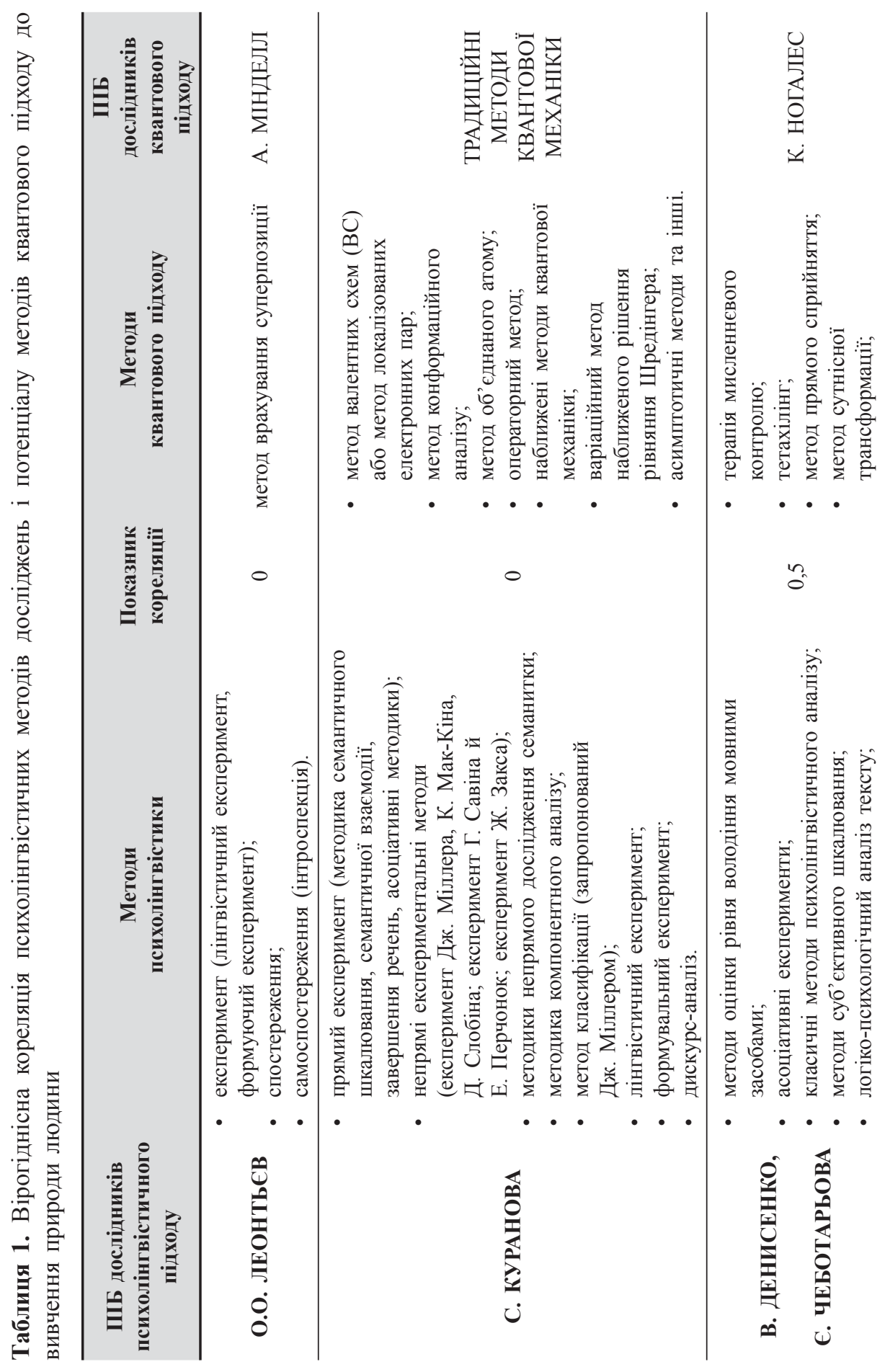


The Problems of Psycholinguistic Research Methodology...

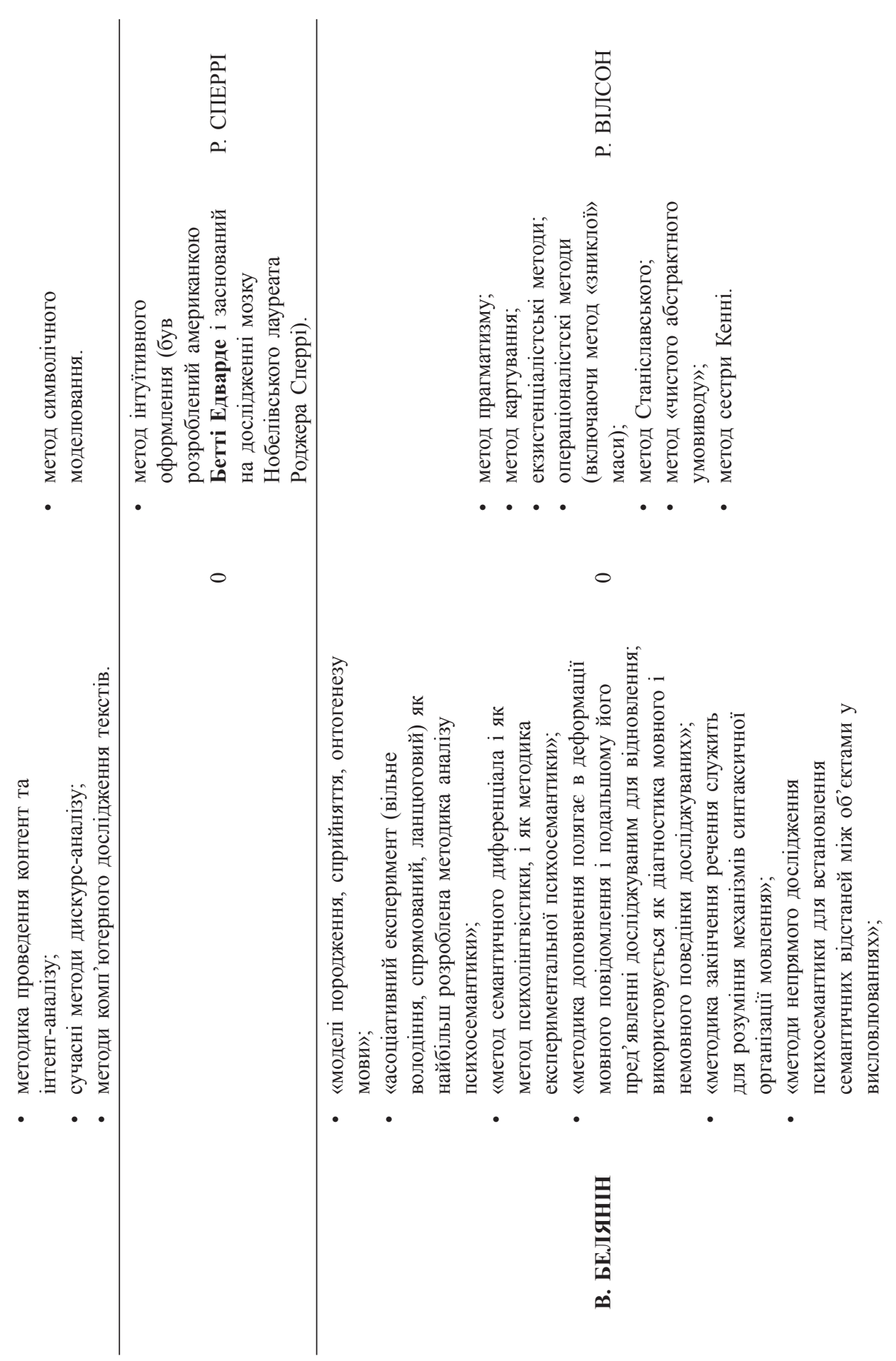




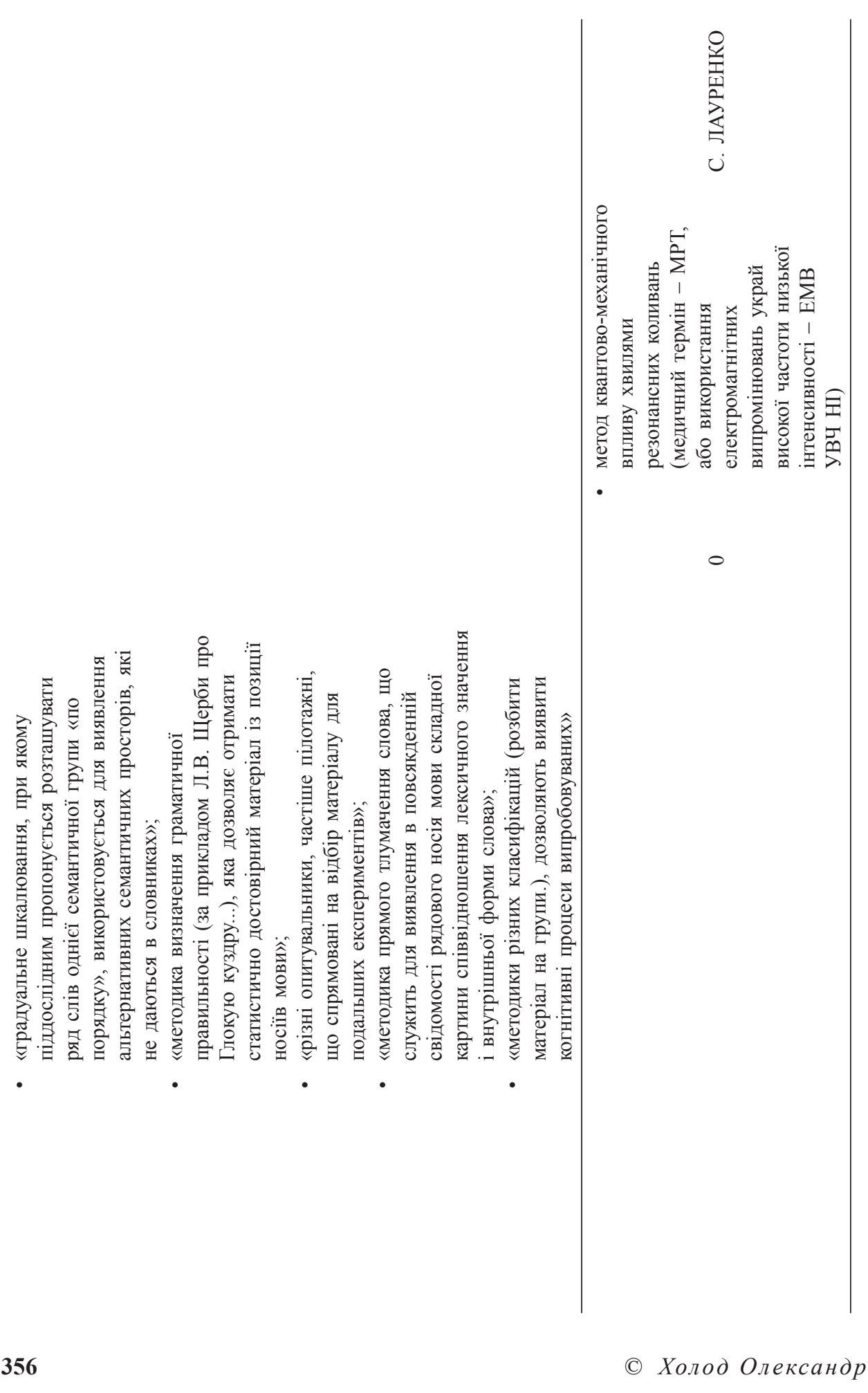


The Problems of Psycholinguistic Research Methodology...

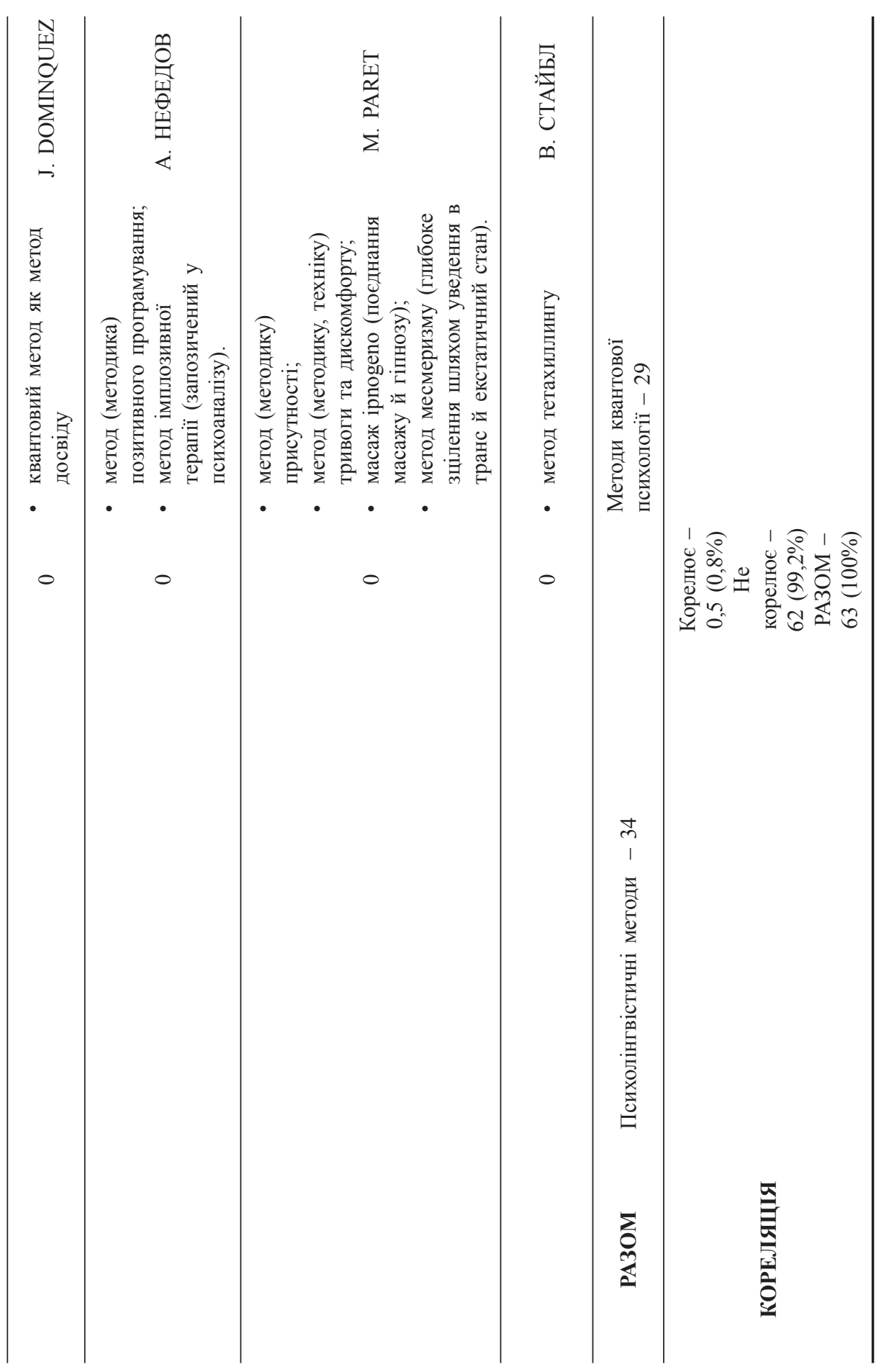

(C) Kholod Alexander 
2) лише один метод психолінгвістики (асоціативний експеримент) був визначений як такий, що де в чому нагадує метод квантової психології (метод прямого сприйняття) і має право на показник 0,5 (половина) від загального показника кореляції $(1,0)$;

3) із $100 \%$ (63) методів психолінгвістики і методів квантової психології лише один метод може вважатися (із великим ступенем вірогідності) таким, що корелює (див. п. 2).

\section{Висновки}

На початку дослідження ми сформулювали мету, суть якої полягала у встановленні можливості поєднання теоретичного потенціалу сучасної психолінгвістики й доведених постулатів квантових теорій формулюванні завдань загаданого поєднання. Після здійсненого дослідження маємо право декларувати, що поставлена мета була досягнута.

За результатами здійсненого теоретичного пошуку ми набули право сформулювати завдання психолінгвістичної методології досліджень з урахуванням квантового підходу та його методології.

Порівняння методів дослідження у психолінгвістиці й квантовій психології дає право констатувати, що на 99,2\% вони не співпадають, або є такими, між якими відсутня кореляція.

1. Факт, декларований у п. 1, тягне за собою висновок про те, що методи психолінгвістики грунтуються на матеріалістичній базі й не можуть бути адекватними й релевантними для квантової психології, яка своїм підгрунтям має такі методи, що наближені до нематеріалістичних.

2. Сформульований у п. 3 висновок наближує нас до твердження про об’єктивну необхідність прийняти методологію квантової психології.

3. Квантова психологія декларує положення про те, що мозок людини не є місцем породження іiї свідомості, а лише інструментом сприйняття й інтерпретації продуктів свідомості. 


\section{Рекомендації}

У зв'язку із сформульованими висновками ми рекомендуємо дослідникам психолінгвістичних процесів, які будуть спиратися на методологію квантової психології, кілька постулатів.

Під час визначення об’єкта дослідження необхідно враховувати принципи суперпозиції процесів ідентифікації продуктів породження й сприйняття мовлення. Пам'ятати, що принципом суперпозиції вважається такий «принцип незалежного накладання діянь або процесів, при якому результуючий ефект еквівалентний об'єднанню (сумі) ефектів, що зумовлені окремо кожним із них» (Принцип суперпозиції, 2018).

1. Відійти від уявлення про лінійний характер процесів породження й сприйняття мовлення на користь голографічного принципу мозкової активності носія мовлення.

2. Враховувати, що вимірювання процесів породження та сприйняття мовлення в присутності спостерігача (експериментатора) відрізняються від тих реальних процесів мозкової діяльності, які відбуваються у його (спостерігача) відсутності.

3. Враховувати тезу про те, що якість думок людини прямо пропорційна певним моделям, схемам, які створюються станами нейронів та їхніх мереж.

Разом із сформульованими висновками, спираючись на думку К. Ногалеса, варто зазначити, що «сьогодні квантова психологія та іiі ідеї набирають все більшу кількість прихильників. Але, зауважує дослідник, - збільшення популярності може привести до того, що прихильники напрямку стануть вважати його єдино вірним або взагалі почнуть проголошувати відверто псевдонаукові речі». К. Ногалес, виходячи зі свого передбачення, логічного визначає завдання, що виникає перед психологами (ми додамо, i перед психолінгвістами тощо): «визначити, що $\epsilon$ істинним, а що - ні, й розробити адекватний теоретичний і методологічний апарати квантової психології» (Ногалес, 2018) (додамо - і квантової психолінгвістики). 


\section{Подяки}

Висловлюємо вдячність професору Ларисі Калмиковій та доценту Наталії Харченко, а також керівництву ДВНЗ «ПереяславХмельницький державний педагогічний університет імені Григорія Сковороди» в особі ректора академіка НАПН України Віктора Коцура та в особі проректора з наукової роботи Сергія Рика й оргкомітету XIII міжнародної науково-практичної конференції «Психолінгвістика в сучасному світі - 2018» за можливість висловити нашу позицію, що грунтується на постулатах квантової механіки й квантової психології.

Наше дослідження не могло бути здійсненим без уважної й толерантної та конструктивної допомоги від професора Василя Крутова - нашого вчителя, наставника й друга, а також без точкових і справедливих зауважень професора Ганни Холод, яким ми щиро вдячні.

\section{Література}

20 интересных фактов о мозге, 2018. Режим доступу: https://soroka-balaboka. livejournal.com/13448.html

Аршинов В.И. Проблема интерпретации квантовой механики и теорема Белла. Теоретическое и эмпирическое в современном научном познании. Москва, 1984. C. 213-233.

Белинский А.В. Квантовая нелокальность и отсутствие априорных значений измеряемых величин в экспериментах с фотонами. Успехи физ. наук. 2003. T. 173(8). C. $905-909$.

Белянин В.П. Психолингвистика / Гл. ред. Д.И. Фельдштейн. Москва : Флинта; Московский психолого-социальный институт, 2003. 232 с.

Вакарчук І.О. Квантова механіка. 4-те вид., доп. Львів : ЛНУ імені Івана Франка, 2012. 872 c.

Волинский С. Квантовое сознание. Изучите квантовую психологию на собственном опыте / предисл. К. Вилсон; пер. с англ. Д. Ивахненко. Киев, 1997.

Выготский Л.С. Мышление и речь. Москва-Ленинград, 1934.

Выготский Л.С. Мышление и речь. Собр. соч. в 6-ти тт. Москва, 1982. Т. 2.

Гавеля О. Основні положення квантово-орбітальної теорії культурології. Вісник Книжкової палати. 2013. № 7. С. 1-4.

Горелов И.Н., Седов К.Ф. Основы психолингвистики. Москва : Лабиринт, 2004. $320 \mathrm{c}$.

Горошко Е.И. Психолингвистика: Интернет-коммуникаций. Bonpocbl психолингвистики. 2008. Вип. 7. 
The Problems of Psycholinguistic Research Methodology...

Гринштейн Дж., Зайонц А. Квантовый вызов. Современные исследования оснований квантовой механики. Изд. 2, испр. и доп. Долгопрудный: Издат. Дом, 2012. 432 с.

Денисенко В.Н., Чеботарева Е.Ю. Современные психолингвистические методы анализа речевой коммуникации. Москва : РУДН, 2008. 258 с.

Дридзе Т.М. Текстовая деятельность в структуре социальной коммуникации: монография. Москва : Наука, 1984. 270 с.

Жинкин Н.И. Механизмы речи. Москва, 1958.

Жинкин Н.И. О кодовых переходах во внутренней речи. Bопросы языкознания. 1964. № 6. С. 26-38.

Засєкіна Л.В., Засєкін С.В. Психолінгвістична діагностика. Луцьк : РВВ «Вежа», Волин. нац. ун-т ім. Лесі Українки, 2008. 188 с.

Залевская А.А. Введение в психолингвистику. Москва, 1999.

Заречный М. Квантово-мистическая картина мира. Структура реальности и путь человека. Москва : ИГ «Весь», 2007.

Засєкіна Л.В., Засєкін С.В. Психолінгвістичні аспекти перекладу. Луцьк, 2006.

Зимняя И.А. Смысловое восприятие речевого сообщения. Смысловое восприятие речевого сообщения (в условиях массовой коммуникации). Москва, 1976. C. 5-33.

Иванов М.Г. Как понимать квантовую механику. Москва; Ижевск : НИЦ «Регулярная и хаотическая динамика», 2012. 516 с.

Калмикова Л.О., Х Харченко Н.В., Дем'яненко С.Д., Порядченко Л.А. Розвиток мовлення дітей старшого дошкільного віку: монографія / За заг. ред. Л.О. Калмикової. Київ: ПП Медвєдєв, 2007. 304 с.

Калмикова Л.О. Психолінгвістичні принципи розвитку мовленнєвої діяльності в старших дошкільників. Психолінгвістика. 2009. Вип. 4.

Карасик В.И. Язык социального статуса. Москва : Ин-т языкознания РАН; Волгоград : Волгоградский гос. пед. ин-т, 1992. 330 с.

Карасик В.И. Языковой круг: Личность, концепты, дискурс. Москва : Гнозис, 2004. 326 c.

Карп’юк М.Д. Психолінгвістика та їі місце серед когнітивно-інформаційних наук. Психолінгвістика / Гол. ред. О.М. Холод. Кривий Ріг : ОНЮА, 2007.

Карпенко И.А. Проблема связи квантовой механики и реальности: в поисках решения. Эпистемология \& философия науки. 2014. № 11(2). С. 110-126.

Клюев Е.В. Речевая коммуникация. Москва : РИПОЛ КЛАССИК, 2002. 320 с.

Красных В.В. Основы психолингвистики и теории коммуникации. Москва : Гнозис, 2001.

Крутов В.В. Возвращение к себе. Основы развития сознания и управления мышлением. Киев : Генеза, 2014. 400 с.

Куранова С.І. Основи психолінгвістики. Київ : Академія, 2012. 208 с.

Лазуренко C.I. Психофізіологічні особливості квантово-механічного впливу. Проблеми сучасної психологї. 2010. Вип. 8.

Леонтьев А.А. Язык, речь, речевая деятельность. Москва, 1969.

Леонтьев А.А. Основы психолингвистики. 3-е изд. Москва : Смысл; СПб. : Лань, 2003. $287 \mathrm{c}$.

Мартинек С. Психолингвистический анализ семантической структуры слов с общим значением «водоем» (на материале русского и украинского языков). Актуальнье проблемы лексикологии: в 2 ч. Даугавпилс, 1991. Ч. 1. 
Менский М.Б. Сознание и квантовая механика: жизнь в параллельных мирах: (чудеса сознания - из квантовой реальности). Фрязино : Век 2, 2011. 320 с.

Миллер Дж. Психолингвисты. Теория речевой деятельности (Проблемы психолингвистики). Москва, 1968.

Минделл А. Геопсихология в шаманизме, физике и даосизме, 2018. [Електронний pecypc]. Режим доступу: https://psy.wikireading.ru/120166

Нефедов А. Управление реальностью с помощью квантовой психологи. Квантовая Магия. 2018. Вып. 4. Т. 2. С. 4218-4242, 2005; також див.: http:// quantmagic.narod.ru/volumes/VOL242005/p4218.html

Ногалес К. Квантовое сознание и квантовый мозг, 2018. [Электронный ресурс]. Режим доступа: https://www.aum.news/psikhologiya/4138-kvantovoe-soznanie-ikvantovyy-mozg

Петрик В.М., Присяжнюк М.М., Компанцева Л.Ф. Сугестивні технології маніпулятивного впливу. Київ : ЗАТ ВІПОЛ, 2011. 248 с.

Печенкин А.А. Квантовая онтология (комментарии к книге Г. Стаппа «Сознание, материя и квантовая механика»). Вестн. Моск. ун-та. Сер. 7. Философия. 2013. № 4. С. 15-27.

Печенкин А.А. Три классификации интерпретаций квантовой механики. Философия науки. 1999. Вып. 5. С. 164-182.

Пищальникова В.А. История и теория психолингвистики: в 2-х ч. Москва : Мос. гос. лингв. ун-т, 2007. Ч. 2. Этнопсихолингвистика. 208 с.

Постовалова В.И. Существует ли языковая картина мира? Язык как коммуникативная деятельность человека. Сб. науч. трудов МГПИИЯ. Москва, 1987. Вып. 284.

Принцип суперпозиції, 2018. [Електронний ресурс]. Режим доступу: https:// uk.wikipedia.org/wiki/Принцип_суперпозиції

Румянцева И.М. Психология речи и лингвопедагогическая психология. Москва : ПЕРСЭ; Логос, 2004. 319 с.

Сахарный Л.В. Введение в психолингвистику. Ленинград : Просвещение, 1989. $184 \mathrm{c}$.

Сорокин Ю.А. Введение в этнопсихолингвистику / под ред. С.А. Борисовой. Ульяновск : УлГУК, 1998. 138 с.

Тарасов Е.Ф. Введение. История психолингвистических школ. Теория речевой деятельности. Москва, 1991.

Терехович В.Э. Сравнительный анализ интерпретаций квантовой механики. Разные взгляды на квантовую реальность, 2014. [Электронный ресурс]. Режим доступу: http://vtpapers.ru/Papers/InterpretationQM_Terekhovich.pdf

Терещук C.I. Методична система формування предметної компетентності старшокласників $з$ квантової фізики. Зб. наук. пращь УДПУ імені Павла Тичини. 2015. Вип. 2(2). С. 396-405.

Уиллсон Р.А. Квантовая психология. Как работа Вашего мозга программирует Вас и Ваш мир, 2018. [Електронний ресурс]. Режим доступу: http://ariom.ru/ litera/wilson/wilson-01.htm

Уфимцева Н.В. Языковое сознание: динамика и вариативность. Москва-Калуга : Институт языкознания РАН, 2011. 252 с.

Фрумкина Р.М. Психолингвистика. Москва: Академия, 2006.

Холод А.М. Психолингвистический аспект анализа проблем взаимосвязи массмедиа и гражданского общества. Масс-медиа и гражданское общество / под 
The Problems of Psycholinguistic Research Methodology...

ред. А.М. Холода. Кривой Рог : Международный исследовательский центр «Человек: язык, культура, познание», 2008б. С. 39-130.

Холод О.М. Методологія досліджень соціальних комунікацій. Львів : ПАІС, 2014. 280 c.

Холод О.М. Нооцентризм як нова методологія психолінгвістики. Матеріали I міжнародного симпозіуму “Світ лінгвістики», 15-16 квітня 2008 року. Кривий Ріг : Міжнародний дослідний центр «Людина: мова, культура, пізнання», 2008a. С. 20-31.

Холод О.М. Психолінгвістичні методи при аналізі соціальних комунікацій. [Електронний ресурс]. Режим доступу: http://www.experts.in.ua/baza/analitic/ index.php?ELEMENT ID=27192

Чему обучает методика ThetaHealing, 2018. [Електронний ресурс]. Режим доступу: http://vct.od.ua/blog/mistika/thetahealing-mgnovennaya-transform aciya-zhizni

Шахнарович А.М., Юрьева Н.М. Психолингвистический анализ семантики и грамматики. Москва, 1990.

Щерба Л.В. О частях речи в русском языке. Языковая система и речевая деятельность. Ленинград, 1974.

Эдварде Б. Художник внутри вас / Пер. с англ.; Худ. обл. Б.Г. Клюйко. Минск : ООО «Попурри», 2000. 256 с.

Янчилин В.Л. Квантовая нелокальность. Москва: Красанд, 2010. 144 с.

Blumenthal, A.L. (1987). The Emergence of Psycholinguistics. Synthese, 72, 313-323. https://doi.org/10.1007/BF00413749

Carroll, D.W. (1994). Psychology of language (2nd ed.). Belmont, CA, US: Thomson Brooks/Cole Publishing Co.

Crespo, A, Rodriguez-Granillo, A, \& Lim, V.T. (2017). Quantum-Mechanics Methodologies in Drug Discovery: Applications of Docking and Scoring in Lead Optimization. Curr Top Med Chem, 17(23), 2663-2680. https://doi.org/10.2174/1 568026617666170707120609

Dominquez, J.M. (2018). Quantum Method: The Secret Code To Make Money. [S1]: Babelcube Inc.

Ervin-Tripp, S.M., \& Slobin, D.I. (1966). Psycholinguistics. Annual Review of Psychology, 17, 435-74. https://doi.org/10.1146/annurev.ps.17.020166.002251

Smith, F., \& Miller, G.A. (1969). The Genesis of Language: A Psycholinguistic Approach. Synthese, 19(3/4), 470-473.

Kess, J.F. (1993). Psycholinguistics: Psychology, Linguistics, and the Study of Natural Language. Amsterdam/Philadelphia: John Benjamins.

Paret, M. (2018). Presence - The Reasoning Behind This Course. Retrieved from http://www.marcoparet.com/training/presence

Wolinsky, S., \& Wilson, C. (1993). Quantum Consciousness: The Guide to Experiencing Quantum Psychology.

Sperry, R.W. (1964). The great cerebral commissure. Scientific American, 210(1), 4252. https://doi.org/10.1038/scientificamerican0164-42

Sperry, R.W. (1969). A modified concept of consciousness. Psychological Review 76(6), 532-536. https://doi.org/10.1037/h0028156

Hameroff, S., \& Penrose, R. (2014a). Consciousness in the universe: A review of the 'Orch OR' theory. Physics of Life Reviews, 11(1), 39-78.

Hameroff, S., \& Penrose, R. (2014b). Reply to criticism of the 'Orch OR qubit''Orchestrated objective reduction' is scientifically justified. Physics of Life Reviews, 11, 104-112. https://doi.org/10.1016/j.plrev.2013.11.014 
Wilson, R.A. (2018). Quantum Psychology. Website. Retrieved from http://www. rawilson.com/quantum.html

\section{References}

20 interesnyh faktov o mozge [20 interesting facts about the brain]. (2018). Retrieved from https://soroka-balaboka.livejournal.com/13448.html [in Russian].

Arshinov, V.I. (1984). Problema interpretacii kvantovoj mekhaniki i teorema Bella [The problem of interpretation of quantum mechanics and Bell's theorem]. Teoreticheskoe $i$ ehmpiricheskoe $v$ sovremennom nauchnom poznanii Theoretical and empirical in modern scientific knowledge, (pp. 213-233). Moscow [in Russian].

Belinskij, A.V. (2003). Kvantovaya nelokalnost i otsutstvie apriornyh znachenij izmeryaemyh velichin $\mathrm{v}$ ehksperimentah $\mathrm{s}$ fotonami [Quantum nonlocality and the absence of a priori values of measured values in experiments with photons]. Uspekhi fiz. nauk. - Successes nat. Sciences, 173(8), 905-909 [in Russian].

Belyanin, V.P. (2003). Psiholingvistika [Psycholinguistics]. D.I. Feldshtejn (Eds.). Moscow : Flinta; Moskovskij psihologo-socialnyj institut [in Russian].

Vakarchuk, I.O. (2012). Kvantova mekhanika [Quantum mechanics] (4nd ed., rev.). Lviv : LNU imeni Ivana Franka [in Ukrainian].

Volinskij, S. (1997). Kvantovoe soznanie. Izuchite kvantovuyu psihologiyu na sobstvennom opyte [Quantum consciousness. Learn quantum psychology first hand]. (D. Ivahnenko, Trans). Kyiv [in Russian].

Vygotskij, L.S. (1934). Myshlenie i rech [Thinking and speaking]. Moscow-Leningrad.

Vygotskij, L.S. (1982). Myshlenie $i$ rech [Thinking and speaking]. (Vols. 1-6). Moscow [in Russian].

Gavelya, O. (2013). Osnovni polozhennya kvantovo-orbitalnoï teoriï kulturologiï [Fundamentally established quantum-orbital theory of cultural science]. Visnik Knizhkovoï palati - Bulletin of the Book Palace, 7, 1-4 [in Ukrainian].

Gorelov, I.N., \& Sedov, K.F. (2004). Osnovy psiholingvistiki [Basics of Psycholinguistics]. Moscow : Labirint [in Russian].

Goroshko, E.I. (2008). Psiholingvistika: Internet-kommunikacij [Psycholinguistics: Internet communications]. Voprosy psiholingvistiki - Psycholinguistic questions, 7 [in Russian].

Grinshtejn, Dzh., \& Zajonc, A. (2012). Kvantovyj vyzov. Sovremennye issledovaniya osnovanij kvantovoj mekhaniki [Quantum challenge. Modern studies of the foundations of quantum mechanics] (2nd td., rev.). Dolgoprudnyj : Izdat. Dom [in Russian].

Denisenko, V.N., \& Chebotareva, E.Yu. (2008). Sovremennye psiholingvisticheskie metody analiza rechevoj kommunikacii [Modern psycholinguistic methods for analyzing speech communication]. Moscow : RUDN [in Russian].

Dridze, T.M. (1984). Tekstovaya deyatelnost v strukture socialnoj kommunikacii [Text activity in the structure of social communication]. Moscow : Nauka [in Russian].

Zhinkin, N.I. (1958). Mekhanizmy rechi [Speech Mechanisms]. Moscow [in Russian].

Zhinkin, N.I. (1964). O kodovyh perekhodah vo vnutrennej rechi [On code transitions in internal speech]. Voprosy yazykoznaniya - Topics in the study of language, 6, 26-38 [in Russian]. 
The Problems of Psycholinguistic Research Methodology...

Zasekina, L.V., \& Zasєkin, S.V (2008). Psiholingvistichna diagnostika [Psycholinguistic diagnosis]. Luck : PBB «Vezha», Volin. nac. un-t im. Lesi Ukraïnki [in Ukrainian].

Zalevskaya, A.A. (1999). Vvedenie v psiholingvistiku [Introduction to psycholinguistics]. Moscow [in Russian].

Zarechnyj, M. (2007). Kvantovo-misticheskaya kartina mira. Struktura realnosti $i$ put cheloveka [Quantum mystical picture of the world. The structure of reality and the way of man]. Moscow : IG «Ves» [in Russian].

Zasєkina, L.V., \& Zasєkin, S.V. (2006). Psiholingvistichni aspekti perekladu [Psycholingvistichn aspects and transfer]. Luck [in Ukrainian].

Zimnyaya, I.A. (1976). Smyslovoe vospriyatie rechevogo soobshcheniya. Smyslovoe vospriyatie rechevogo soobshcheniya (v usloviyakh massovoyj kommunikacii) The semantic perception of a speech message (in terms of mass communication), (pp. 5-33). Moscow [in Russian].

Ivanov, M.G. (2012). Kak ponimat kvantovuyu mekhaniku [How to understand quantum mechanics]. Moscow; Izhevsk : NIC «Regulyarnaya i haoticheskaya dinamika» [in Russian].

Kalmykova, L.O. (2009). Psiholingvistichni principi rozvitku movlennevoï diyalnosti v starshih doshkilnikiv [Psycholingvistichni principle rozvitku ovlennvovoj doyalnost in the senior preschool children]. Psiholingvistika - Psycholinguistics, 4 [in Ukrainian].

Karasik, V.I. (1992). Yazyk socialnogo statusa [The language of social status]. Moscow : In-t yazykoznaniya RAN; Volgograd : Volgogradskij gos. ped. in-t [in Russian].

Karasik, V.I. (2004). Yazykovoj krug: Lichnost, koncepty, diskurs [Language circle: Personality, concepts, discourse]. Moscow : Gnozis [in Russian].

Karpyuk, M.D. (2007). Psiholingvistika ta ii misce sered kognitivno-informacijnih nauk [Psycholinguistic and psychology of the cognitive-informative sciences]. Psiholingvistika - Psycholinguistics. O.M. Kholod (Eds.). Krivij Rig : ONYUA [in Ukrainian].

Karpenko, I.A. (2014). Problema svyazi kvantovoj mekhaniki i realnosti: v poiskah resheniya [The problem of communication between quantum mechanics and reality: in search of a solution]. Epistemologiya \& filosofiya nauki Epistemology \& Philosophy of Science, 11(2), 110-126 [in Russian].

Klyuev, E.V. (2002). Rechevaya kommunikaciya [Speech Communication]. Moscow : RIPOL KLASSIK [in Russian].

Krasnyh, V.V. (2001). Osnovy psiholingvistiki i teorii kommunikacii [Fundamentals of Psycholinguistics and Communication Theory]. Moscow : Gnozis [in Russian].

Krutov, V.V. (2014). Vozvrashchenie $k$ sebe. Osnovy razvitiya soznaniya $i$ upravleniya myshleniem [Return to herself. Fundamentals of the development of consciousness and thinking thinking]. Kyiv : Geneza [in Russian].

Kuranova, S.I. (2012). Osnovi psiholingvistiki [Fundamentals of psycholinguistics]. Kyiv : Akademiya [in Ukrainian].

Lazurenko, S.I. (2010). Psihofiziologichni osoblivosti kvantovo-mekhanichnogo vplivu [Psychophysiological features of quantum-mechanical influence]. Problemi suchasnoï psihologii - Problems of modern psychology, 8 [in Ukrainian].

Leontev, A.A. (1969). Yazyk, rech, rechevaya deyatelnost [Language, speech, speech activity]. Moscow [in Russian]. 
Leontev, A.A. (2003). Osnovy psiholingvistiki [Fundamentals of psycholinguistics] (4nd ed.). Moscow : Smysl; Saint Petersburg : Lan [in Russian].

Martinek, S. (1991). Psiholingvisticheskij analiz semanticheskoj struktury slov s obshchim znacheniem «vodoem» (na materiale russkogo i ukrainskogo yazykov) [Psycholinguistic analysis of the semantic structure of words with the general meaning of the «reservoir» (on the material of the Russian and Ukrainian languages)]. Aktualnye problemy leksikologii - Actual problems of lexicology (Vols. 1) [in Russian].

Menskij, M.B. (2011). Soznanie i kvantovaya mekhanika: zhizn v parallelnyh mirah: (chudesa soznaniya - iz kvantovoj realnosti) [Consciousness and quantum mechanics: life in parallel worlds: (miracles of consciousness - from quantum reality)]. Fryazino : Vek 2 [in Russian].

Miller, Dzh. (1968). Psiholingvisty. Teoriya rechevoj deyatelnosti (Problemy psiholingvistiki) [Psycholinguists. Theory of speech activity (Problems of psycholinguistics)]. Moscow [in Russian].

Mindell, A. (2018). Geopsihologiya v shamanizme, fizike $i$ daosizme [Geopsychology in shamanism, physics and Taoism]. Retrieved from https://psy.wikireading. $\mathrm{ru} / 120166$ [in Russian].

Nefedov, A. (2018). Upravlenie realnostyu s pomoshchyu kvantovoj psihologi [Management of reality with the help of a quantum psychologist]. Kvantovaya Magiya - Quantum Magic, 4(2), 4218-4242, 2005. Retrieved from http:// quantmagic.narod.ru/volumes/VOL242005/p4218.html [in Russian].

Nogales, K. (2018). Kvantovoe soznanie i kvantovyj mozg [Quantum Consciousness and Quantum Brain]. Retrieved from https://www.aum.news/psikhologiya/4138kvantovoe-soznanie-i-kvantovyy-mozg [in Russian].

Petrik, V.M., Prisyazhnyuk, M.M., \& Kompanceva, L.F. (2011). Sugestivni tekhnologii manipulyativnogo vplivu [Suggestive technologies of manipulative influence]. Kyiv : ZAT VIPOL [in Ukrainian].

Pechenkin, A.A. (2013). Kvantovaya ontologiya (kommentarii k knige G. Stappa «Soznanie, materiya i kvantovaya mekhanika») [Quantum ontology (comments on the book G. Stappa «Consciousness, matter and quantum mechanics»)]. Vestn. Mosk. un-ta. Ser. 7. Filosofiya - Bulletin of Moscow University. Series 7. Philosophy, 4, 15-27 [in Russian].

Pechenkin, A.A. (1999). Tri klassifikacii interpretacij kvantovoj mekhaniki [Three Classifications of Interpretations of Quantum Mechanics]. Filosofiya nauki Philosophy of Science, 5, 164-182 [in Russian].

Pishchalnikova, V.A. (2007). Istoriya $i$ teoriya psiholingvistiki [History and theory of psycholinguistics]. Moscow : Mos. gos. lingv. un-t [in Russian].

Postovalova, V.I. (1987). Sushchestvuet li yazykovaya kartina mira? Yazyk kak kommunikativnaya deyatelnost cheloveka [Is there a linguistic picture of the world? Language as a communicative activity of a person]. Sb. nauch. trudov MGPIIYA - Collection of scientific works of MGPII, 284 [in Russian].

Princip superpozicii [Principle of superposition] (2018). Retrieved from https:// uk.wikipedia.org/wiki/Princip_superpoziciï [in Ukrainian].

Kalmykova, L.O., Kharchenko, N.V., Demyanenko, S.D., \& Poryadchenko, L.A. (2007). Rozvitok movlennya ditej starshogo doshkilnogo viku [Development of speech for children of senior preschool age]. L.O. Kalmykova (Eds.). Kyiv : PP Medved€v [in Ukrainian]. 
Rumyanceva, I.M. (2004). Psihologiya rechi $i$ lingvopedagogicheskaya psihologiya [Psychology of speech and linguistic-pedagogical psychology]. Moscow : PERSEH; Logos [in Russian].

Saharnyj, L.V. (1989). Vvedenie v psiholingvistiku [Introduction to Psycholinguistics]. Leningrad : Prosveshchenie [in Russian].

Sorokin, Yu.A. (1998). Vvedenie $v$ etnopsiholingvistiku [Introduction to Ethnopsycholinguistics]. S.A. Borisovoj (Ed.). Ulyanovsk : UlGUK [in Russian].

Tarasov, E.F. (1991). Vvedenie. Istoriya psiholingvisticheskih shkol. Teoriya rechevoj deyatelnosti [Introduction. History of psycholinguistic schools. Theory of speech activity]. Moscow [in Russian].

Terekhovich, V.E. (2014). Sravnitelnyj analiz interpretacij kvantovoj mekhaniki. Raznye vzglyady na kvantovuyu realnost [Comparative analysis of the interpretations of quantum mechanics. Different views on quantum reality]. Retrieved from http:// vtpapers.ru/Papers/InterpretationQM_Terekhovich.pdf [in Russian].

Tereshchuk, S.I. (2015). Metodichna sistema formuvannya predmetnoï kompetentnosti starshoklasnikiv z kvantovoï fiziki [Methodical system of formation of the subject competence of senior pupils from quantum physics]. Zb. nauk. prac UDPU imeni Pavla Tichini - Pavel Tychyna collection of scientific works of UDPU, 2(2), 396-405 [in Ukrainian].

Uillson, R.A. (2018). Kvantovaya psihologiya. Kak rabota Vashego mozga programmiruet Vas $i$ Vash mir [Quantum psychology. How does your brain work for you and your world]. Retrieved from http://ariom.ru/ litera/wilson/wilson-01. htm [in Russian].

Ufimceva, N.V. (2011). Yazykovoe soznanie: dinamika $i$ variativnost [Linguistic Consciousness: Dynamics and Variability]. Moscow-Kaluga : Institut yazykoznaniya RAN [in Russian].

Frumkina, R.M. (2006). Psiholingvistika [Psycholinguistics]. Moscow : Akademiya [in Russian].

Kholod, A.M. (2008b). Psiholingvisticheskij aspekt analiza problem vzaimosvyazi mass-media i grazhdanskogo obshchestva [Psycholinguistic aspect of the analysis of the problems of the interconnection of mass media and civil society]. Massmedia $i$ grazhdanskoe obshchestvo - Mass-media media and civil society. A.M. Kholod (Eds.), (pp. 39-130). Krivoj Rog : Mezhdunarodnyj issledovatelskij centr «Chelovek: yazyk, kultura, poznanie» [in Russian].

Kholod, O.M. (2014). Metodologiya doslidzhen socialnih komunikacij [Methodology of studies of social communications]. Lviv : PAIS [in Ukrainian].

Kholod, O.M. (2008a). Noocentrizm yak nova metodologiya psiholingvistiki [Noocentrism as a new methodology of psycholinguistics]. Proceedings from: Materiali I mizhnarodnogo simpoziumu «Svit lingvistiki» - Materials of the I International Symposium "The World of Linguistics». (pp. 20-31). Krivij Rig : Mizhnarodnij doslidnij centr «Lyudina: mova, kultura, piznannya» [in Ukrainian].

Kholod, O.M. (n.d.). Psiholingvistichni metodi pri analizi socialnih komunikacij [Psycholinguistic methods in the analysis of social communications]. Retrieved from http://www.experts.in.ua/baza/analitic/index.php?ELEMENT_ID=27192 [in Ukrainian].

Chemu obuchaet metodika ThetaHealing [What ThetaHealing teaches]. (2018). Retrieved from http://vct.od.ua/blog/mistika/thetahealing-mgnovennaya-transform aciya-zhizni [in Russian]. 
Shahnarovich, A.M., \& Yureva, N.M. (1990). Psiholingvisticheskij analiz semantiki $i$ gramatiki [Psycholinguistic analysis of semantics and grammar]. Moscow [in Russian].

Shcherba, L.V. (1974). O chastyah rechi v russkom yazyke [About parts of speech in Russian]. Yazykovaya sistema i rechevaya deyatelnost - Language system and speech activity. Leningrad [in Russian].

Edvarde, B. (2000). Hudozhnik vnutri vas [Artist inside you]. (B.G. Klyujko, Trans). Minsk : OOO «Popurri» [in Russian].

Yanchilin, V.L. (2010). Kvantovaya nelokalnost [Quantum nonlocality]. Moscow : Krasand [in Russian].

Blumenthal, A.L. (1987). The Emergence of Psycholinguistics. Synthese, 72, 313-323. https://doi.org/10.1007/BF00413749

Carroll, D.W. (1994). Psychology of language. (2nd ed.). Belmont, CA, US: Thomson Brooks/Cole Publishing Co.

Crespo, A, Rodriguez-Granillo, A, \& Lim, V.T. (2017). Quantum-Mechanics Methodologies in Drug Discovery: Applications of Docking and Scoring in Lead Optimization. Curr Top Med Chem, 17(23), 2663-2680. https://doi.org/10.2174/1 568026617666170707120609

Dominquez, J.M. (2018). Quantum Method: The Secret Code To Make Money. [S1]: Babelcube Inc.

Ervin-Tripp, S.M., \& Slobin, D.I. (1966). Psycholinguistics. Annual Review of Psychology, 17, 435-74. https://doi.org/10.1146/annurev.ps.17.020166.002251

Smith, F., \& Mill, G.A. (1969). The Genesis of Language: A Psycholinguistic Approach. Synthese, 19(3/4), 470-473.

Kess, J.F. (1993). Psycholinguistics: Psychology, Linguistics, and the Study of Natural Language. Amsterdam/Philadelphia: John Benjamins.

Paret, M. (2018). Presence - The Reasoning Behind This Course. Retrieved from http://www.marcoparet.com/training/presence

Wolinsky, S., \& Wilson, C. (1993). Quantum Consciousness: The Guide to Experiencing Quantum Psychology.

Sperry, R.W. (1964). The great cerebral commissure. Scientific American, 210(1), 42-52. https://doi.org/10.1038/scientificamerican0164-42

Sperry, R.W. (1969). A modified concept of consciousness. Psychological Review 76(6), 532-536. https://doi.org/10.1037/h0028156

Hameroff, S., \& Penrose, R. (2014a). Consciousness in the universe: A review of the 'Orch OR' theory. Physics of Life Reviews, 11(1), 39-78.

Hameroff, S., \& Penrose, R. (2014b). Reply to criticism of the 'Orch OR qubit''Orchestrated objective reduction' is scientifically justified. Physics of Life Reviews, 11, 104-112. https://doi.org/10.1016/j.plrev.2013.11.014

Wilson, R.A. (2018). Quantum Psychology. Website. Retrieved from http://www. rawilson.com/quantum.html

\section{АНОТАЦІЯ}

У статті автор аналізує проблему відсутності знань про те, якими можуть бути методи досліджень у психолінгвістиці з позицій постулатів квантових теорій. 
Mета дослідження полягає у встановленні можливості поєднання теоретичного потенціалу сучасної психолінгвістики й доведених постулатів квантових теорій та формулюванні завдань загаданого поєднання.

Методологією дослідження були обрані як діалектичний, так $i$ метафрізичний методи. Із числа загальнонаукових автор обрав методи аналізу й синтезу, класифікації. Методика дослідження передбачала такі основні процедури: ідентифрікація критеріїв, за якими можлива подальша класифрікація існуючих методів, що пов'язані з вивченням природи людини, самоктуалізачії iї внутрішніх ресурсів на покращення власного здоров'я, успіху й безпеки; визначення завдань психолінгвістичної методології досліджень у межах методології квантових теорій і галузей знань; визначення вірогіднісної кореляції психолінгвістичних методів досліджень $і$ потенціалу методів квантового підходу до вивчення природи людини й побудова таблиці на базі згаданої кореляції; визначення завдань психолінгвістичної методології досліджень з урахуванням потенціалу методів, що пов'язані з вивченням квантових процесів, парадоксів та ефектів; подання рекомендацій $і$ завдань психолінгвістики в застосуванні методів квантового підходу.

у висновках свого дослідження автор встановив, що методи психолінгвістики грунтуються на матеріалістичній базі й не можуть бути адекватними й релевантними для квантової психології, яка своїм підгрунтям має такі методи, що наближені до нематеріалістичних. Саме тому слід прийняти, на думку автора, методологію квантової психології, яка декларує положення про те, що мозок людини не є місцем породження ії свідомості, а лише інструментом сприйняття й інтерпретації продуктів свідомості.

Ключові слова: методи, квантовий підхід, психолінгвістичні методи, методи квантової механіки, суперпозиція.

\section{Холод Александр. Задачи психолингвистической методологии исследований и квантовый подход}

\section{АННОТАЦИЯ}

В статье автор анализирует проблему отсутствия знаний о том, какими могут быть методы исследований в психолингвистике с позиций постулатов квантовых теорий.

Цель исследования заключается в установлении возможности сочетания теоретического потенциала современной психолингвистики и доказанных постулатов квантовых теорий и формулировке задач задуманного сочетания.

Методологией исследования стали как диалектический, так и метафизический методы. Из числа общенаучных автор выбрал методы анализа и синтеза, классификации. Методика исследования предусматривала следующие основные процедуры: идентификация критериев, по которым возможна дальнейшая классификация существующих методов, связанных с изучением природы человека, самоктуализации ее внутренних ресурсов на 
улучшение собственного здоровья, удачи и безопасности; определение задач психолингвистической методологии исследований в рамках методологии квантовых теорий и областей знаний; определение вероятностной корреляции психолингвистических методов исследований и потенциала методов квантового подхода к изучению природы человека и построение таблицы на базе упомянутой корреляции; определение задач психолингвистической методологии исследований с учетом потенциала методов, связанных с изучением квантовых прочессов, парадоксов и эфректов; представление рекомендаций и задач психолингвистики в применении методов квантового подхода.

В выводах своего исследования автор установил, что методы психолингвистики основываются на материалистической базе $и$ не могут быть адекватными и релевантными для квантовой психологии, методі которой приближенны к нематериалистическим. Именно поэтому следует принять, по мнению автора, методологию квантовой психологии, декларирующую положение о том, что мозг человека не является местом порождения его сознания, а лишь инструментом восприятия и интерпретации продуктов сознания.

Ключевые слова: методы, квантовый подход, психолингвистические методы, методы квантовой механики, суперпозиция. 